\title{
HAKIKATTANGGUNG JAWAB SOSIAL BUMN TERHADAP STAKEHOLDER
}

\author{
Abdul Rauf \\ Sekolah Tinggi Manajemen Informatika dan Komputer (STMIK)Dipanegara Makassar \\ Dosen Hukum Perusahaan \\ Email : a_rauf2002@yahoo.com
}

\begin{abstract}
ABSTRAK
Tanggungjawab sosial dan lingkungan bagi perusahaan penting untuk menjaga kelangsungan produksi sampai pada tujuan membangun legitimasi sosial.Namun masih terdapat pertentangan pendapat, terutama yang berkaitan dengan hakikat serta perlunya tanggung jawab sosial dan lingkungan diatur secara formal dalam perundang-undangan. Penelitian ini bertujuan untuk mengetahui hakikat tanggung jawab sosial dan lingkungan pada perusahaan BUMN di Sulawesi Selatan. Penelitian ini dilakukan mengkaji teori-teori hukum dihubungkan dengan tanggung jawab sosial dan lingkungan. Sedangkan untuk kajian normatifnya dilakukan dengan menganalisis ketentuan perundang-undangan (in abstracto) yang relevan dan melihat penerapannya (In concreto). Populasi penelitian meliputi seluruh BUMN yang berbentuk perseroan terbatas di Sulawesi Selatan. Kemudian ditetapkan secara sengaja 5 (lima) BUMN sebagai sampel (purposive sampling).Hasil penelitian menunjukkan bahwa tanggung jawab sosial dan lingkungan pada hakikatnya ada karena adanya kepentingan-kepentingan yang melekat di dalamnya. Motivasi utama yang mendorong dilaksanakannya tanggung jawab sosial dan lingkungan bukan karena faktor kedermawanan sosial semata, melainkan karena adanya faktor kepentingan didalamnya.Sehingga pelaksanaannya merupakan wujud upaya pemenuhan terhadap kepentingan tersebut secara seimbang dan adil, baik bagi perusahaan maupun terhadap stakeholder pada umumnya. Pertentangan seringkali timbul karena aspek keadilan dan keseimbangan kentingan ini tidak terpenuhi dengan baik. Keseimbangan kepentingan hanya dapat dicapai melalui suatu mekanisme pengaturan berdasarkan ketentuan hukum yang berlaku dan pelaksanaannya bersifat mandatory.Alasan utama sehingga pelaksanaan tanggung jawab sosial dan lingkungan perlu diwajibkan yaitu pandangan bahwa tanggung jawab sosial dan lingkungan adalah bentuk kedermawanan sosial yang sifatnya sukarela, tidak sejalan dengan akibat yang ditimbulkannya. Selain itu membiarkan pihak lain menderita gangguan ataupun kerugian tanpa dasar yang cukup untuk dapat melakukan tuntutan menurut hukum merupakan suatu bentuk ketidakadilan. Disimpulkan bahwa tanggung jawab sosial dan lingkungan pada perusahaan bukanlah kedermawanan sosial semata, melainkan karena ada kepentingan didalamnya. Kepentingan ini harus dipenuhi secara seimbang dan adil bagi semua pihak, untuk itu diperlukan pengaturan menurut ketentuan hukum yang berlaku.
\end{abstract}

Kata Kunci : Tanggung sosial dan lingkungan, BUMN, PKBL

\begin{abstract}
Social and environmental responsibility for companies is important to maintain continuity of production to the goal of establishing social legitimacy. But there is still a disagreement, particularly with regard to the nature and necessity of social and environmental responsibility is set formally in the law. This study aims to determine the nature of social and environmental responsibility in state-owned enterprises in South Sulawesi. This research was done reviewing the legal theories linked to social and environmental responsibility. As for the normative study conducted by analyzing the provisions of the legislation (in abstracto) relevant and see its application (In concreto). The study population includes all state-owned limited liability company in South Sulawesi. Then set intentionally 5 (five) SOE as samples (purposive sampling) The results of the study showed that social and environmental responsibility is essentially there for their interests inherent in it. The primary motivation that drives the implementation of social and environmental responsibility not because of the charitable giving alone, but for their in deed execution. Therefore interest factor is a form of compliance efforts against the interests of a balanced and fair, both the company and the stakeholders in general. Contradictions often arise because of the aspect of
\end{abstract}


fairness and balance is have not met political well. Balance of interests can only be achieved through an adjustment mechanism based on the applicable law and its implementation is a major mandatory. The reason is so that the implementation of social and environmental responsibility must be obligated the view that social and environmental responsibility is a form of charitable voluntary, not in line with the result thereof. Additionally let others suffer disruption or loss without sufficient basis to be able to claim under the law is a form of injustice. It was concluded that social and environmental responsibility in the company's charitable giving is not alone, but because there is interest in it. These interests must be met in a balanced and fair to all parties, it is necessary arrangement in accordance with applicable law.

Keywords: social and environmental responsibility, state, PKBL

\section{A. PENDAHULUAN}

Perusahaan sesungguhnya tidak hanya memiliki sisi tanggung jawab ekonomis kepada para shareholders seperti memperoleh profit dan menaikkan harga saham, atau tanggung jawab legal kepada pemerintah, seperti membayar pajak, memenuhi persyaratan AMDAL dan ketentuan lainnya. Namun, jika perusahaan ingin tetap eksis dan akseptabel, maka harus pula menjalankan tanggungjawabnya yang bersifat sosial(Yusuf Wibisono, (2007).

Walaupun berbagai pihak telah mengkampanyekan pentingnya tanggungjawab sosial bagi perusahaan, baik untuk menjaga kelangsungan produksi sampai pada tujuan membangun legitimasi sosial, namun masih terdapat pertentangan pendapat mengenai hakikat tanggungjawab sosial perusahaan (Reza Rahman,2009). Jika ditelusuri secara lebih mendalam, hal tersebut berkaitan erat dengan konsep mengenai fungsi dasar kegiatan bisnis dan hubungannya dengan institusi lain dalam masyarakat, termasuk pemerintah. Pertentangan itu antara lain mengenai : Apakah tanggung jawab sosial perusahaan itu berada pada ranah etika yaitu etika bisnis (Priyanto Susiloadi,2008) atau harus berada pada ranah hukum. Apakah tanggung jawab sosial perusahaan perlu diatur atau tidak perlu diatur secara formal dalam perundang-undangan yang disertai dengan sanksi-sanksi tegas. Apakah perangkat peraturan yang ada relatif cukup mengatur tercapainya perimbangan kepentingan antara perusahaan dengan masyarakat secara baik dan adil. Bila dilihat lebih dalam lagi pertentangan muncul sangat erat kaitannya dengan landasan filosofis serta pandangan etika atau moral mengenai bisnis. Bahkan timbul juga pertanyaan bahwa apakah lembaga bisnis dapat dituntut memiliki suara hati (conscience) sebagaimana halnya individu.

Badan Usaha Milik Negara (BUMN) merupakan salah satu elemen 
utama kebijakan ekonomi negara. Keberadaan BUMN mempunyai peran utama dalam pembangunan. BUMN diperlukan dalam pengaturan infrastruktur dan public utilitie.Oleh karena itu, BUMN menempatkan dirinya pada hampir seluruh aktivitas ekonomi (Fernandes Praxy,1985). Namun demikian posisi BUMN dipandang "ambigu" karena berada pada dua sisi yakni sebagai institusi bisnis dan alat negara. Sebagai istitusi bisnis, terdapat ekspektasi yang kuat agar BUMN seharusnya beroperasi sebagaimana layaknya sebuah perusahaan untuk menghasilkan laba, namun disisi lain BUMN juga dituntut untuk berfungsi sebagai instrument pembangunan nasional dan kebijakan sosial(Fajar Nursahid, 2006).

Pelaksanaan tanggung jawab sosial dan lingkungan oleh BUMN diwujudkan dalam bentuk Program Kemitraan dan Bina Lingkungan (PKBL). Hal ini menarik untuk dikaji karena adanya faktor pembeda antara BUMN dengan perusahaan swasta lainnya, yang secara normatif mendukung kegiatan kedermawanan sosial pada perusahaan BUMN. Pertama, karena sifat dan statusnya sebagai perusahaan milik negara, BUMN tidak terkendala oleh motif pengurangan pajak (tax deduction) sebagaimana menjadi pengharapan perusahaan-perusahaan swasta. Walaupun pajak tetap merupakan kewajiban bagi BUMN, kewajiban ini tidak serta merta mempengaruhi kelancaran kegiatan atau operasi BUMN. Kedua, terdapat instrumen pemaksa berupa kebijakan pemerintah melalui Pasal 2 ayat (1) Permen BUMN Nomor : 05/MBU/2007, perusahaan BUMN diwajibkan menjalankan Program Kemitraan dan Bina Lingkungan (PKBL). Sehingga praktik derma yang imperatif tersebut memungkinkan bahwa potensi sumbangan sosial perusahaanperusahaan BUMN seharusnya lebih besar. Lebih lanjut, praktik kedermawanan sosial BUMN yang bersifat imperatif juga bertolak belakang dengan filosofi kedermawanan itu sendiri yang bersifat sukarela, oleh karena itu sangat mungkin terdapat kompleksitas permasalahan, khususnya yang berkaitan dengan hakikat dan motivasi berderma serta keberlanjutan praktik kedermawanan sosial tersebut.

\section{B. METODE PENELITIAN}

Penelitian ini dilakukan di Provinsi Sulawesi Selatan dengan pertimbangan bahwa taraf hidup 
masyarakat Sulawesi Selatan yang pada umumnya masih tergolong belum maju dibanding dengan kota-kota besar lain di Indonesia, maka tentulah berbagai macam bentuk program pengembangan sosial masih sangat dibutuhkan. Selain itu, pengaturan mengenai tanggung jawab sosial dan lingkungan pada perusahaan BUMN berlaku secara nasional, sehingga setiap BUMN memiliki pedoman yang sama dalam pelaksanaan tanggung jawab sosial dan lingkungan.Penelitian ini mengkaji hakikat tanggung jawab sosial pada perusahaan BUMN yang didasarkan pada teori-teori yang dijadikan sebagai dasar dalam penulisan. Kemudian untuk kajian normatifnya dilakukan dengan cara menganalisis ketentuan perundang-undangan yang relevan dan melihat penerapannya di lapangan. Hasil penelitiannya akan dipaparkan secara jelas dan sistematis.

Berdasarkan hal tersebut di atas, maka penelitian ini termasuk penelitian di bidang hukum perusahaan. Penelitian ini merupakan jenis penelitian normatif dan empiris, yaitu penelitian hukum yang kajiannya meliputi ketentuanketentuan perundang-undangan (in abstracto) serta penerapannya di lapangan (In concreto). Tipe penelitian hukumnya adalah deskriptif, yaitu memaparkan secara lengkap, rinci, dan sistematis.Populasi dalam penelitian ini adalah BUMN yang berbentuk perseroan terbatas dengan jumlah keseluruhan sebanyak 26 perusahaan(BPS Sulsel, 2009). Perusahaan BUMN yang dijadikan sampel ditentukan dengan pertimbangan bahwa memiliki kantor yang berdomisili di Sulawesi Selatan, kegiatan usahanya di bidang sumber daya alam dan/atau berkaitan dengan sumber daya alam, atau memiliki aktifitas cukup menonjol dalam pelaksanaan tanggung jawab sosial dan lingkungan.

Jumlah sampel yang diambil dalam penelitian ini sebanyak 5 perusahaan. Penentuan sampel ini dilakukan dengan cara sengaja (purposive sampling). Responden dalam penelitian ini total sebanyak 105 orang yang terdiri atas : Pimpinan perusahaan sebanyak 1 orang, kepala bagian sebanyak 5 orang, ketua serikat pekerja, dan karyawan sebanyak 10 orang pada masing-masing BUMN sampel.Ditambah dengan 5 pengusaha kecil menengah yang diikutsertakan pada program PKBLdi masing-masing BUMN sampel. 
Pengumpulan data dilakukan dengan cara pembagian kuesioner dan wawancara. Kuesioner diberikan kepada setiap responden di masingmasing perusahaan. Kuesioner ini diarahkan kepada pimpinan/top manajemen, pimpinan serikat pekerja dan karyawan pada masing-masing perusahaan sampel. Sedangkan wawancara dilakukan dengan bantuan daftar pertanyaan pemandu (guided questionaire). Wawancara diarahkan kepada para pengusaha kecil menengah yang ikut serta pada program sosial dari perusahaan BUMN.

Data yang diperoleh di lapangan akan dianalisis sesuai dengan karkteristik data yang bersangkutan. Untuk data yang berupa angka-angka akan dibuat dalam bentuk tabel kemudian dijelaskan secara deskriptif. Analisa data dilakukan secarakualitatif.

C. PEMBAHASAN HASIL PENELITIAN DAN ANALISIS

\section{Hakikat Tanggung Jawab Sosial dan Lingkungan}

Pemahaman yang menunjukkan bahwa tanggung jawab sosial dan lingkungan dilaksanakan untuk kepentingan perusahaan, dibuktikan dengan banyaknya pemikiran yang berusaha memberikan argumen, untuk menunjukkan bahwa tanggung jawab sosial dan lingkungan dimaksudkan untuk kepentingan perusahaan itu sendiri. Argumen-argumen tersebut antara lain menyatakan bahwa tanggung jawab sosial dan lingkungan dilaksanakan untuk memperbaiki citra perusahaan (Dwi Kartini,2009), merupakan investasi sosial untuk keberlanjutan perusahaan itu sendiri di masa yang akan datang (Edi Suharto, 2010). Keseluruhan hasil pemikiran tersebut menggambarkan bahwa tanggung jawab sosial dan lingkungan dilaksanakan untuk kepentingan perusahaan itu sendiri.

Tanggung jawab sosial dan lingkungan bukanlah masalah moral atau kebaikan hati perusahaan semata, namun yang lebih menonjol adalah faktor kepentingan perusahaan, baik kepentingan yang bersifat internal yaitu kepentingan ekonomi, maupun kepentingan yang bersifat eksternal berupa perbaikan citra dan upayaupaya untuk mengamankan operasional perusahaan dari berbagai macam tekanan atau tuntutan, baik dari penguasa maupun dari masyarakat sendiri (Jimmy Tanaya,2004).

Dari segi pelaksanaannya, tanggung jawab sosial dan lingkungan 
oleh perusahaan BUMN diwujudkan dalam bentuk Program Kemitraan dan Bina Lingkungan (PKBL). Berdasarkan hasil wawancara dan informasi yang diperoleh dari kuesioner, yang diedarkan pada 5 BUMN yang dijadikan sampel, dua diantaranya yaitu PT. Kawasan Industri Makassar (PT.KIMA) dan PT. Perkebunan Nusantara (PTPN XIV) mengartikan bahwa PKBL adalah wujud tanggung jawab sosial dan lingkungan pada perusahaan BUMN. Sedangkan tiga BUMN sampel yang lain, menganggap bahwa tanggung jawab sosial dan lingkungan pada perusahaan BUMN selain diwujudkan dalam bentuk program PKBL juga disertai dengan program-program lain yang dananya bukan diambil dari laba perusahaan, akan tetapi diambil dari biaya perseroan. Ketiga BUMN yang dimaksud adalah PT. Pelabuhan Indonesia IV (Pelindo), PT. Semen Tonasa, dan PT. Telekomunikasi Indonesia (Telkom).

Dalam praktiknya, programprogram sosial di luar PKBL yang ditujukan untuk kepentingan masyarakat dan lingkungan diwujudkan dalam bentuk dan jenis kegiatan yang berbeda-beda oleh masing-masing BUMN sampel. PT. Semen Tonasa misalnya menetapkan bahwa bantuan untuk pembinaan olah raga dan kesenian merupakan suatu program tersendiri di luar dari program PKBL. Sedangkan PT. Pelindo IV dan PT. Telkom tidak menetapkan secara khusus mengenai jenis kegiatan sosial tertentu di luar dari PKBL. Programprogram seperti ini sangat ditentukan oleh kebijakan masing-masing perusahaan BUMN yang bersangkutan.

Berdasarkan hasil penelitian dari 5 BUMN yang dijadikan sampel, tiga diantaranya menetapkan dua macam jenis anggaran. Ketiga BUMN yang dimaksud adalah PT. Pelabuhan Indonesia IV (Pelindo), PT. Semen Tonasa, dan PT. Telekomunikasi Indonesia (Telkom). Ketiga BUMN ini menafsirkan bahwa tanggung jawab sosial dan lingkungan pada BUMN adalah program PKBL ditambah dengan kegiatan lain di luar dari yang diatur dalam Permen PER-05/MBU/2007. Sedangkan dua BUMN lain yang menjadi sampel yaitu PT. Kawasan Industri Makassar (KIMA) dan PT. Perkebunan Nusantara melaksanakan tanggung jawab sosial dan lingkungan dalam bentuk PKBL.

Hakikat diartikan sebagai realitas atau kenyataan yang sebenarnya. Bukan 
kenyataan sementara atau keadaan yang menipu, juga bukan kenyataan yang berubah (Amsal Bakhtiar, 2004). Berangkat dari pemahaman akan realitas atau kenyataan yang sebenarnya, maka tanggung jawab sosial dan lingkungan pada hakikatnya ada karena adanya kepentingankepentingan yang melekat di dalamnya. Keberadaan atau lahirnya tanggung jawab sosial dan lingkungan dimotivasi oleh adanya muatan kepentingankepentingan tersebut. Oleh karena itu, pelaksanaannya merupakan suatu bentuk upaya pemenuhan terhadap kepentingan-kepentingan yang menjadi muatannya itu. Pemenuhan kepentingan-kepentingan tersebut harus dilaksanakan secara seimbang, agar tidak menimbulkan benturanbenturan. Dalam hal inilah dibutuhkan pengaturan-pengaturan atau hukum.Walaupun ada nuansa etis dan moral dalam pelaksanaannya, namun itu hanyalah realitas semu. Keberadaan tanggung jawab sosial dan lingkungan tidak sempurna menunjukkan dirinya sebagai suatu bentuk kedermawanan sosial. Tanggung jawab sosial dan lingkungan lebih menampakkan wajahwajah kepentingan yang melekat padanya.Nuansa moral dan etis inilah yang seringkali memberikan gambaran bahwa tanggung jawab sosial dan lingkungan merupakan bentuk kedermawanan sosial. Pertanyaan mendasar dari sudut pandang ontology yang menyatakan bahwa "apa itu tanggung jawab sosial dan lingkungan?". Maka jawabnya, "itu adalah kepentingan-kepentingan, yang mewujud dalam suatu bentuk kedermawanan sosial".

Praktik kedermawanan sosial yang seringkali nampak dalam pelaksanaan tanggung jawab sosial dan lingkungan bukanlah kenyataan yang sesungguhnya. Tanggung sosial dan lingkungan dilaksanakan bukanlah semata-mata karena bermaksud untuk berbuat baik atau berderma secara ikhlas tanpa pamrih. Tanggung jawab sosial dan lingkungan dilaksanakan juga bukan atas dasar sukarela semata. Selain karena adanya tuntutan hukum, tanggung jawab sosial dan lingkungan dilaksanakan juga karena adanya tuntutan kepentingan, baik untuk kepentingan perusahaan maupun karena adanya tuntutan situasi atau kondisi sosial masyarakat pada umumnya. Tuntutan-tuntutan seperti inilah yang seringkali memaksa pihak perusahaan untuk melaksanakan 
tanggung jawab sosial dan lingkungan. Oleh karena itu, sifat sukarela dari praktik tanggung jawab sosial dan lingkungan juga bukan merupakan kenyataan yang sesungguhnya. Sifat tanggung jawab sosial dan lingkungan pada hakikatnya merupakan suatu keharusan yang mesti dijalankan oleh perusahaan, agar dapat terus berjalan dengan baik dan berkelanjutan (sustainable).

Dari segi pelaksanannya, tanggung jawab sosial dan lingkungan pada hakikatnya adalah upaya untuk mewujudkan keseimbangan kepentingan dari berbagai pihak yang terkait. Dengan demikian, pertanyaan dari sudut pandang epistemology yaitu "bagaimana cara atau metode yang benar dalam melaksanakan tanggung jawab sosial dan lingkungan". Jawabnya adalah "harus dilakukan secara seimbang, adil dan merata". Sehingga dapat dipahami bahwa pelaksanaan tanggung jawab sosial dan lingkungan merupakan suatu cara atau metode yang dilakukan oleh pihak perusahaan untuk pemenuhan kepentingan para pihak yang terkait secara seimbang, adil dan merata.

Pertentangan-pertentangan yang timbul terkait dengan pelaksanaan tanggung jawab sosial dan lingkungan, seringkali disebabkan oleh adanya ketidakseimbangan diantara kepentingan-kepentingan yang terkait, sehingga kurang mencerminkan keadilan dan pemerataan. Hal ini menunjukkan bahwa dari aspek epistemologi, pada hakikatnya tanggung jawab sosial dan lingkungan harus dilaksanakan untuk kepentingan semua pihak. Oleh karena itu, peraturan yang dibuat juga harus mampu mewadahi kepentingan semua pihak yang terkait, mulai dari kepentingan perusahaan, kepentingan sosial dan lingkungan, bahkan kepentingan pemerintah. Dalam hal ini tidak ada kepentingan yang boleh diabaikan, karena hal itu akan menimbulkan ketidakseimbangan dari setiap komponen kepentingan yang ada.

Bilamana keseimbangan kepentingan dari semua pihak tidak terpenuhi, maka hal itu akan selalu menimbulkan pertentangan atau perdebatan-perdebatan mulai dari tataran teoritis sampai pada praktisnya. Karena setiap pihak tentu akan berusaha untuk mempertahankan kepentingannya masing-masing. Akibatnya adalah akan sulit untuk melahirkan suatu acuan atau format baku yang bersifat tetap mengenai 
tanggung jawab sosial dan lingkungan, baik pada tingkat pengaturan sampai pada pelaksanaannya.

Selanjutnya dari sudut pandang aksiologi, pertanyaan mendasar yang perlu dijawab adalah untuk apa tanggung jawab sosial dan lingkungan dilaksanakan, apa kegunaan atau manfaat yang dapat diperoleh. Pertanyaan-pertanyaan ini dapat dijawab dengan melihat berbagai macam kepentingan yang terkait.Dari segi kepentingan perusahaan, kegunaan atau nilai manfaat yang dapat diperoleh adalah dapat meningkatkan citra perusahaan sekaligus sebagai suatu upaya untuk tetap mempertahankan eksistensi perusahaan agar dapat beroperasi secara berkelanjutan (sustainable). Sedangkan dari sudut pandang para pemangku kepentingan (stakeholder), tanggung jawab sosial dan lingkungan berfungsi sebagai landasan atau dasar dalam upaya pendistribusian nilai-nilai manfaat yang telah diperoleh perusahaan dari aktivitasnya kepada para pemangku kepentingan. Dalam hal ini, tanggung jawab sosial dan lingkungan yang dilaksanakan oleh perusahaan BUMN berguna untuk meningkatkan kualitas kehidupan sosial dan lingkungan yang bermanfaat, baik bagi perseroan sendiri, komunitas setempat, maupun bagi masyarakat secara menyeluruh.Pelaksanaan tanggung jawab sosial dan lingkungan diharapkan dapat memberi manfaat yang sebesar-besarnya bagi terwujudnya kemakmuran rakyat secara adil dan merata.

Berdasarkan ketentuan Pasal 33 UUD RI 1945 ayat (3), pengelolaan perekonomian nasional Indonesia diorientasikan pada upaya mewujudkan kemakmuran rakyat yang sebesarbesarnya. Hal ini sejalan dengan teori negara kesejahteraan. Dalam teori ini, negara memiliki peran yang besar dalam mengalokasikan dan mendistribusikan setiap sumber daya untuk pemenuhan kebutuhan dasar warganya. Dalam upaya mewujudkan kesejahteraan bagi seluruh rakyatnya, negara Indonesia kemudian menguasai setiap potensi-potensi kekayaan alam yang bernilai strategis, termasuk cabang-cabang produksi yang penting dan menguasai hajat hidup orang banyak untuk dapat dikelola dengan baik dan selanjutnya dimanfaatkan untuk sebesar-besar kemakmuran rakyat. Hal inilah yang mendasari lahirnya perusahaan-perusahaan milik negara yang disebut Badan Usaha Milik 
Negara (BUMN). Berdasarkan ketentuan undang-undangsesuai dengan fungsi dan peranannya, BUMN diwajibkan untuk melaksanakan tanggung jawab sosial dan lingkungan sebagai suatu upaya untuk mewujudkan kesejahteraan bersama bagi seluruh rakyatnya. Dengan demikian dapat dipahami bahwa tanggung jawab sosial dan lingkungan yang melekat pada BUMN merupakan tugas konstitusional yang harus dilaksanakan dalam kerangka memajukan kesejahteraan bagi seluruh rakyat. Sehingga sasaran pelaksanaan tanggung jawab sosial dan lingkungan bukan hanya ditujukan kepada stakeholder semata, akan tetapi bagi seluruh rakyat Indonesia. Hal ini tentu berbeda dengan konsep tanggung jawab sosial yang dipahami sebelumnya, yang lebih menitik beratkan pada upaya pemenuhan kepentingan para stakeholder yaitu pihak-pihak yang terpengaruh atau berpengaruh terhadap perusahaan.

Agar kesejahteraan bersama bagi seluruh rakyat dapat tercapai dengan baik, maka pelaksanaan tanggung jawab sosial dan lingkungan oleh perusahaan BUMN semestinya diarahkan pada upaya pencapaian kesejahteraan bagi seluruh rakyat Indonesia. Hal ini sesuai dengan amanat UUD 1945, yang sejalan dengan konteks negara kesejahteraan yaitu mewujudkan kesejahteraan setinggi-tingginya bagi sebanyakbanyaknya orang (the greatest happiness for the greatest number). Pihak perusahaan dapat diarahkan untuk menyasar bidang-bidang tertentu atau kelompok-kelompok masyarakat yang belum sepenuhnya tersentuh oleh program-program pemerintah. Walaupun demikian kepentingan perusahaan harus tetap diperhatikan.

\section{Pentingnya Tanggung Jawab Sosial dan Lingkungan Diatur Berdasarkan Hukum}

Teori keadilan menurut John Rawls (1995:72) dengan prinsip ketidaksamaannya (the principle of difference) menekankan bahwa ketidaksamaan yang ada diantara manusia, dalam bidang ekonomi dan sosial, harus diatur sedemikian rupa, sehingga ketidaksamaan tersebut, dapat menguntungkan setiap orang, terutama bagi orang-orang yang secara kodrati kurang beruntung. Hal ini menunjukkan bahwa perlu ada pengaturan. Walaupun dalam teorinya, John Rawls lebih menekankan pada kesepakatankesepakatan sebagai dasar dalam melakukan pengaturan, namun 
kesepakatan atau kontrak sesungguhnya juga dijalankan berdasarkan hukum.

Terlebih lagi teori negara kesejahteraan, yang memberikan peran besar kepada negara atau pemerintah untuk menjamin kesejahteraan warganya. BUMN sebagai badan usaha milik negara memiliki tanggung jawab konstitusional untuk ikut serta berpartisipasi mewujudkan kesejahteraan masyarakat secara adil dan merata. Begitu pula dengan Wealth Maximization Theory of Justiceyang sudah dari awal menggunakan pendekatan hukum dalam menganalisis masalah-masalah ekonomi dan menekankan bahwa hukum seharusnya mempromosikan efisiensi (Richard A. Posner, 1992). Teori-teori yang diungkapkan ini menunjukkan bahwa permasalahan ekonomi pada umumnya, terutama dalam hal pendistribusian sumber daya atau potensi-potensi ekonomi secara adil dan merata harus didasarkan pada suatu pengaturan tertentu. Dengan demikian, pelaksanaan tanggung jawab sosial dan lingkungan pada perusahaan BUMN sebagai bagian dari upaya pendisitribusian sumber daya atau potensi ekonomi harus diatur berdasarkan ketentuan hukum yang berlaku. Pengaturan ini dilakukan dalam kerangka pemeratan hasil-hasil pembangunan untuk memberikan manfaat yang sebesar-besarnya bagi kemakmuran rakyat, terutama bagi golongan masyarakat yang kurang beruntung.

Hal ini merupakan jawaban dari ungkapan-ungkapan yang mempertanyakan bahwa apakah tanggung jawab sosial dan lingkungan perlu diatur atau tidak. Dengan kata lain, jika tanggung jawab sosial dan lingkungan dipahami sebagai suatu bentuk kedermawanan sosial yang bersifat sukarela, maka pelaksanaannya tentu akan diserahkan pada pihak perusahaan, dan negara tidak perlu turut campur dengan menetapkan peraturan-peraturan tertentu berdasarkan ketentuan hukum yang berlaku. Akan tetapi, titik berat pemahaman mengenai tanggung jawab sosial dan lingkungan terletak pada aspek kepentingan semua pihak yang terkait. Hal inilah yang harus diperhatikan dan dipenuhi dengan baik. Pemenuhan kepentingan ini perlu diseimbangkan atau dilakukan secara proporsional, melalui mekanisme pengaturan. Pada tataran ini, tanggung jawab sosial dan lingkungan pada 
perusahaan, yang awalnya hanya dipahami sebagai suatu tanggung jawab moral, kemudian bergeser menjadi tanggung jawab hukum yang bersifat mandatory. Sehingga sifat pelaksanaannya pun bergeser dari sesuatu yang bersifat sukarela (voluntary) menjadi bersifat mandatory. Tanggungjawab sosial dan lingkungan yang ada pada perusahaan, pada dasarnya bukanlah tanggungjawab yang semata-mata timbul karena kesalahan (fault), akan tetapi merupakan tanggung jawab yang sudah melekat pada perusahaan sebelum timbulnya suatu kejadian (ex-ante liability). Tanggung jawab sebelum timbulnya kejadian dimaksudkan untuk memberikan sesuatu yang layak kepada publik berdasarkan peraturan atau ketentuan hukum yang berlaku. Sedangkan tanggung jawab setelah kejadian (ex-post liability) adalah tanggung jawab untuk memulihkan keadaan bagi pihak yang dirugikan kepada keadaan semula yang direpresentasikan dengan pembayaran sejumlah ganti rugi yang sesuai dengan kerugian yang diderita sebagai bentuk kompensasi.

Aktivitas yang dilakukan oleh pihak perusahaan dapat menimbulkan dampak bagi pihak-pihak terkait atau para pemangku kepentingan (stakeholder). Aktivitas perusahaan seringkali menimbulkan gangguan bahkan kerugian baik terhadap lingkungan sosial atau masyarakat pada umumnya maupun pencemaran terhadap lingkungan alam. Merugikan pihak lain atau menimbulkan pencemaran terhadap lingkungan adalah suatu bentuk perbuatan yang melanggar hukum. Oleh karena itu seharusnya dapat dituntut menurut ketentuan hukum yang berlaku. Pihak perusahaan seharusnya dapat dituntut untuk memberikan kompensasi, baik berupa perbaikan fasilitas lingkungan sosial maupun lingkungan hidup, termasuk upaya-upaya peningkatan taraf hidup masyarakat sehingga menjadi lebih mandiri dan dapat memfasilitasi dirinya dengan membangun perumahan layak huni sehingga dampak dari aktivitas perusahaan, misalnya debu dan kebisingan dapat ditekan atau dikurangi.

Pemahaman yang menganggap bahwa tanggung jawab sosial dan lingkungan merupakan wujud kedermawanan sosial dengan sifatnya yang sukarela tidak selaras dengan 
akibat yang ditimbulkannya, karena dasar pelaksanaannya hanya merupakan tanggung jawab moral, sementara akibatnya adalah akibat hukum. Hal ini akan menimbulkan kesulitan dalam pengenaan sanksi hukum, karena sanksi yang mungkin diterapkan dalam konteks ini adalah sanksi moral pula. Oleh karena itu seharusnya tanggung jawab sosial dan lingkungan diartikan sebagai tanggung jawab hukum yang sifatnya wajib.

Selain itu, aktivitas perusahaan dapat menimbulkan kerugian bagi pihak lain atau masyarakat walaupun sifatnya tanpa kesalahan, misalnya debu yang beterbangan karena lalu lalangnya kendaraan berat, atau kebisingan yang timbul dari aktivitas pabrik. Hal ini merupakan sesuatu yang sifatnya wajar dan tidak dapat dihindari, karena begitulah aktivitas pabrik. Akan tetapi, apakah karena ini sifatnya wajar dan tanpa kesalahan, sehingga masyarakat harus dibiarkan mengisap debu dan terganggu oleh kebisingan setiap hari. Tentu hal ini akan melahirkan ketidakadilan ditengah-tengah masyarakat. Oleh karena itulah, atas dasar keadilan maka masyarakat atau pihak-pihak yang dirugikan wajib diberikan kompensasi, sebagai konsekuensi hubungan kausalitas dari tindakan atau aktivitas yang dilakukan oleh pihak perusahaan. Atas dasar inilah pelaksanaan tanggung jawab sosial dan lingkungan harus diwajibkan. Sehingga masyarakat yang merasa dirugikan akan memiliki dasar yang cukup untuk dapat melakukan tuntutan.

Bila tuntutan masyarakat terkait dengan aktivitas perusahaan tidak diakomodir atau tidak diatur dengan jelas dalam ketentuan hukum, termasuk dasar pijakannya untuk melakukan tuntutan bilamana ada yang merasa dirugikan, maka masyarakat pada akhirnya akan mengambil jalan sendiri. Jalan yang paling sering ditempuh adalah demonstrasi yang seringkali berujung pada tindakan-tindakan tertentu, yang sifatnya merugikan kepentingan perusahaan atau bahkan bertentangan dengan ketentuan hukum yang berlaku. Terdapat dua alasan utama yang dapat dijadikan dasar, sehingga pelaksanaan tanggung jawab sosial dan lingkungan perlu diwajibkan yaitu : 1) Dilihat dari sudut pandang akibat yang ditimbulkannya,pandangan bahwa tanggung jawab sosial dan lingkungan adalah bentuk kedermawanan sosial yang sifatnya sukarela, tidak sejalan dengan akibat 
yang ditimbulkannya. 2) Dilihat dari sudut pandang keadilan, bahwa membiarkan pihak lain menderita gangguan ataupun kerugian tanpa dasar yang cukup untuk dapat melakukan tuntutan menurut ketentuan hukum yang berlaku merupakan suatu bentuk ketidakadilan. Oleh karena itu, tanggung jawab sosial dan lingkungan perlu diwajibkan.

Menetapkan tanggung jawab sosial dan lingkungan sebagai suatu tanggung jawab hukum dan bukan semata-mata tanggung jawab moral akan memberikan posisi yang sederajat bagi semua pihak, selain itu juga akan memberikan dasar bagi pihak-pihak yang dirugikan untuk melakukan tuntutan. Jika tanggung jawab sosial dan lingkungan hanya dipahami sebagai tanggung jawab moral yang diwujudkan dalam bentuk kedermawanan sosial, maka posisi dari para pihak yang terkait didalamnya menjadi tidak sederajat. Pihak yang melakukan derma atau pihak pemberi akan memiliki posisi yang lebih tinggi dibanding dengan pihak penerima dan jika ada kerugian sulit untuk melakukan tuntutan karena dasarnya adalah sukarela. Namun jika tanggung jawab sosial dan lingkungan dipahami sebagai tanggung jawab hukum, maka akan menimbulkan hak dan kewajiban. Pihak pemberi yaitu perusahaan melaksanakan tanggung jawab sosial dan lingkungan bukan karena sedang berderma namun melaksanakan kewajibannya, dan pihak penerima bukan menerima kebaikan hati, akan tetapi sedang memperoleh haknya menurut hukum. Sehingga hubungan yang timbul diantara para pihak adalah hubungan hukum karena adanya hak dan kewajiban.

Perbandingan antara tanggung jawab sosial dan lingkungan sebagai tangung jawab moral dengan tanggung jawab hukum digambarkan dalam bentuk bagan sebagai berikut :

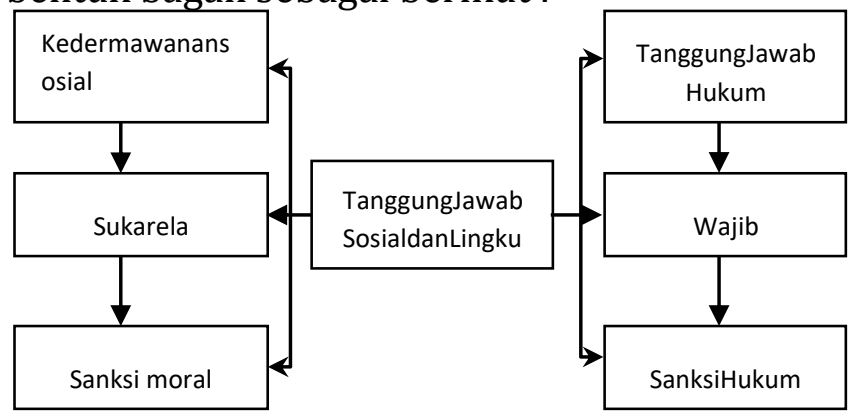

Bagan : Perbandingan Tanggung Jawab Sosial dan Lingkungan Sebagai Tangung Jawab Moral Dengan Tanggung Jawab Hukum

\section{Sinkronisasi Peraturan Tentang}

\section{Pelaksanaan TJSL pada BUMN}

Dasar hukum pelaksanaan Tanggung Jawab Sosial dan Lingkungan (TJSL) oleh BUMN adalah UU No.19 Tahun 2003,yang diwujudkan lebih lanjut dalam Permen No.05-MBU-2007 tentang PKBL, yang kemudian 
ditindaklanjuti dengan Surat Edaran Menteri Negara BUMN No : SE07/MBU/2008 tentang Pelaksanaan PKBL dan Penerapan Pasal 74 UU No. 40 tahun 2007 tentang Perseroan Terbatas. Dengan demikian, dapat dipahami bahwa pelaksanaan PKBL oleh BUMN selain didasarkan pada UU BUMN juga didasarkan pada UU Perseroan Terbatas yang kemudian dijabarkan lebih lanjut dalam PP No. 47 tahun 2012 tentang Tanggung Jawab Sosial dan Lingkungan Perseroan Terbatas.

Peraturan-peraturan tersebut di atas menggunakan istilah yang tidak seragam. Berdasarkan UUPT dan PP No.47 Tahun 2012, istilah yang digunakan adalah "tanggung jawab sosial dan lingkungan". Sedangkan menurut UU BUMN menggunakan istilah "fungsi pelayanan kemanfaatan umum" yang diwujudkan dalam bentuk PKBL. Begitu pula dalam hal dengan sumber pendanaannya, UU BUMN menyatakan bahwa dana pelaksanaan PKBL bersumber dari penyisihan sebagian laba bersih perusahaan, sedangkan dalam UUPT dana pelaksanaan TJSL bersumber dari biaya perseroan. Perbedaan sumber biaya dalam hal pelaksanaan tanggung jawab sosial dan lingkungan pada perusahaan
BUMN antara ketentuan yang terdapat dalam UU BUMN dengan UU PT menjadi masalah tersendiri bagi pihak perusahaan, terutama dalam hal penentuan dan pengalokasian anggaran. Sebagian perusahaan BUMN menetapkan dua jenis pos anggaran yaitu anggaran untuk dana PKBL yang bersumber dari penyisihan laba perusahaan dan anggaran untuk program-program lain di luar program PKBL yang oleh pihak perusahaan disebut dengan istilah dana CSR. Sumber dananya diambil dari biaya operasional perusahaan.Berdasarkan uraian ini, dapat dipahami bahwa terdapat perbedaan mengenai sumber pembiayaan dalam pelaksanaan tanggung jawab sosial dan lingkungan pada BUMN. Selain itu berdasarkan ketentuan dalam UU BUMN dan penjabarannya, sifat pelaksanaan PKBL adalah wajib. Sedangkan dalam UU PT, pelaksanaan TJSL hanya wajib bagi perseroan yang kegiatan usahanya bergerak dibidang dan atau berkaitan dengan sumber daya alam.

Adanya ketidaksesuaian antara UU BUMN dengan UUPT, mulai dari istilah yang digunakan, sumber pembiayaan, sampai pada penetapan wajib serta sanksinya, akan 
menimbulkan kesulitan dalam pelaksanaan tanggung jawab sosial dan lingkungan pada perusahaan BUMN. Oleh karena itu, idealnya perlu ada pengaturan yang lebih jelas dan terperinci tentang tanggung jawab sosial dan lingkungan pada perseroan, mulai dari sumber pembiayaan, termasuk indikator-indikator yang diperlukan untuk melakukan penilaian, sampai pada sanksi yang dapat dijatuhkan bilamana pihak perusahaan tidak menjalankan tanggung jawab sosial dan lingkungannya dengan baik. Peraturan ini juga harus sejalan dan tidak tumpang tindih dengan berbagai peraturan perundang-undangan lainnya.

\section{PENUTUP}

Berdasarkan uraian pada bagian pembahasan, maka dapat disimpulkan bahwa keberadaan tanggung jawab sosial dan lingkungan dimotivasi oleh adanya muatan kepentingan didalamnya. Pemenuhan kepentingan-kepentingan tersebut harus dilaksanakan secara seimbang agar tidak menimbulkan pertentangan, sehingga dibutuhkan pengaturan atau hukum. Oleh karena itu, tanggung jawab sosial dan lingkungan pada hakikatnya adalah suatu bentuk upaya yang harus dijalankan oleh perusahaan secara seimbang dalam memenuhi kepentingan semua pihak, sehingga dapat terwujud kesejahteraan secara adil dan merata. Ketentuan yang mengatur mengenai tanggung jawab sosial dan lingkungan pada BUMN masih perlu disinkronisasikan mulai dari penggunaan istilah, ketentuan tentang sumber pembiayaan, sampai pada penetapan wajib serta sanksinya, agar tidak menimbulkan kesulitan dalam pelaksanaannya.

\section{DAFTAR PUSTAKA}

Amsal Bakhtiar. 2004. Filsafat Ilmu. PT. Rajagrafindo Persada. Jakarta.

BPS Sulsel, 2009. Direktori Perusahaan, Katalog 2009.

Dwi Kartini, 2009. Corporate Social Responsibility: Transformasi Konsep Sustainability Management dan Implementasi di Indonesia. PT. Refika Aditama. Bandung.

Edi Suharto. 2007. Memperkuat tanggung jawab sosial perusahaan (corporate social responsibility). Refika Aditama. Bandung.

Fajar Nursahid, 2006. Praktik kedermawanan sosial BUMN:Analisis Terhadap Model Kedermawanan PT. Karakatau Steel, 
PT.Pertamina, dan PT. Telkom.

Galang, Jurnal Filantropi dan

Masyarakat Madani Vol. 1, No.2 Januari 2006.

Fernandes, Praxy.1985. Nodal Centres

for Public Enterprises. Essays on

Relations Between Governments and Public Enterprises.Ljubljana, Yugoslavia. International Center for Public Enterprises in Developing Country (ICPE).

Jimmy Tanaya. 2004. Tanggung Jawab Sosial Korporasi, The Business Watch Indonesia-Widya Sari Press, Jakarta.

John Rawls. 1995. A Theory of Justice, Teori Keadilan. Diterjemahkan oleh Uzair Fauzan dan Heru Prasetyo. Pustaka Pelajar, Yogyakarta.

Priyanto Susiloadi. 2008. Implementasi

Corporate Social Responsibility Untuk Mendukung Pembangunan

Berkelanjutan. Jurnal Spirit Publik Vol.4No.2 Hal 123-140 ISSN.19070489 Oktober 2008.

Reza Rahman. 2009. Corporate Social Responsibility : Antara Teori dan Kenyataan. Media Pressindo Cet.I. Yogyakarta.

Richard A. Posner. 1992. Economic Analysis of Law, Fourth Edition,
Little, Brown And Company, Boston, Toronto, London.

Yusuf Wibisono. 2007. Membedah Konsep dan Aplikasi CSR, CV.Ashkaf Media Grafika, Surabaya. 